\title{
Dimensões do cotidiano no cancioneiro de João Bosco e Aldir Blanc
}

Alexandre Felipe Fiuza ${ }^{1}$

\section{RESUMO}

Este artigo analisa parte da extensa produção musical da dupla de compositores brasileiros João Bosco e Aldir Blanc, com canções que tiveram como tema o cotidiano das classes populares, em canções compostas do início da década de 1970 até o final da ditadura, em 1985. Portanto, este cancioneiro se encontra localizado temporalmente durante a ditadura militar brasileira, inclusive, contrastando e produzindo dissonâncias no ideário autoritário que tipificava os militares e civis no poder, como também produzindo um discurso contra-hegemônico. Para tanto, este trabalho examina as canções, buscando levar em consideração os gêneros musicais empregados, bem como a ambientação sonora que incorpora as letras. Traz como escopo teórico algumas reflexões sobre o cotidiano a partir de Agnes Heller (2004) e Vinci de Moraes (2000), bem como se pauta numa discussão do campo da sociologia da música e da historiografia da música. Por fim, se detém no exame das canções e discos da dupla, estabelecendo conexões com os intertextos e referenciais históricos inerentes às composições.

Palavras-chave: Cotidiano; Canção; Ditadura; João Bosco e Aldir Blanc.

\section{Dimensions of daily life in the songbook of João Bosco and Aldir Blanc}

\section{ABSTRACT}

This article analyzes part of the extensive musical production of the Brazilian duo composers João Bosco and Aldir Blanc, with songs that had as a theme the daily life of the popular classes, in songs composed from the beginning of the decade of 1970 until the end of the dictatorship in 1985. This songbook is therefore temporarily located during the Brazilian military dictatorship, including contrasting and producing dissonances between the authoritarian ideology that typified the military and civilians in power, as well as producing a counter-hegemonic discourse. For this, this work examines the songs, seeking to take into account the musical genres employed, as well as the sound environment that incorporates the lyrics. It brings as a theoretical scope some reflections on the daily life from Agnes Heller (2004) and Vinci de Moraes (2000), as well as a discussion on the field of sociology of music and the historiography of music. Finally, it stops in the examination of the songs and discs of the pair, establishing connections with the intertexts and historical references inherent to the compositions.

KEYWORDS: Daily life; Song; Dictatorship; João Bosco and Aldir Blanc.

1 Professor de Pedagogia da UNIOESTE - Universidade Estadual do Oeste do Paraná. Doutor em História pela UNESP/ Assis. 


\section{Introdução}

Não era apenas a crítica política à ditadura que preocupava a censura brasileira durante a ditadura militar (1964-85), também a exposição das mazelas sociais era passível de interdição. Igualmente, os temas considerados imorais também passavam pelo crivo censório, e não unicamente durante as ditaduras, afinal, antes do Golpe de 1964 e mesmo depois do fim da ditadura, a censura moral continuou sendo exercida. Por sua vez, no período de 1985 a 1988, o foco dos vetos recaiu sobre os temas morais, já não abrangendo significativamente os temas políticos. Ademais, o fim da Censura no Brasil contemporâneo é indicativo da especificidade do governo autoritário implantado pelos militares, uma vez que somente com a promulgação da Constituição de 1988 que as divisões de Censura foram extintas. Enfim, este dado é sintomático das arbitrariedades presentes no autoritarismo brasileiro.

Durante a ditadura militar, canções que retratavam o cotidiano das classes populares também eram objeto de preocupação da Censura, primeiramente porque colocavam em xeque o mito do "Brasil Grande" dos militares, desvelando a farsa que representava o "milagre econômico" para a maioria da população brasileira. Por conseguinte, as relações entre cotidiano, política e moral obviamente não possuíam fronteiras rígidas. $\mathrm{O}$ discurso que atentava à moral, alardeada pelos militares e civis que apoiavam e administravam a ditadura, guardava estreita aproximação com cosmovisões que abarcavam práticas sociais que se associavam à política. No que concerne ao cotidiano, estes padrões comportamentais não aceitos pelo status quo eram contrastantes com a moral católica e o discurso moralizante do trabalho. Portanto, a prostituição, as ditas perversões sexuais, o consumo de drogas, o enaltecimento à uma suposta vagabundagem, a frequência aos bares, o consumo de materiais pornográficos fotográficos e literários ${ }^{2}$, entre outros, eram passíveis de censura. Curiosamente, mesmo canções que criticavam estes comportamentos também podiam ser censuradas.

Para discutir tal temática, este artigo se detém em algumas composições sobre o cotidiano, compostas pela dupla João Bosco e Aldir Blanc, cuja produção musical se deu de princípios da década de 1970 até por volta do fim da ditadura militar. Este cancioneiro produzido por eles, obviamente, não se restringiu ao tema do cotidiano das classes trabalhadoras, uma vez que, assim como os inúmeros gêneros musicais trabalhados, também guardou uma diversidade temática a ser considerada. O exercício censório, por sua vez, dificultou, mas não impediu, a verve criativa da dupla. Suas canções são igualmente elucidativas dos embates entre Estado e compositores, mas também elas mesmas são expressões do cotidiano das classes populares no período. Por fim, não há como não se reportar a uma outra marca desta produção e desta dupla, o principal instrumento utilizado, no caso, o violão de João Bosco. Afinal, é um instrumento intrinsecamente ligado às camadas populares pelo seu baixo custo e pela possibilidade de aprendizado menos complexo que outros instrumentos, como o piano. Portanto, até na sonoridade, estas mediações entre as culturas populares e as camadas médias e intelectualizadas da população encontraram zonas de contato e surtiram trocas muito produtivas no campo da cultura.

\section{O cotidiano e a canção}

Ao analisarmos a extensa e profícua produção musical da dupla de compositores brasileiros João Bosco e Aldir Blanc, encontramos uma recorrente e criativa tematização envolvendo

2 Expressivo exemplo vem da escritora Odete Rios que, com o pseudônimo Cassandra Rios, teve entre seus 36 livros publicados, 33 proibidos pela ditadura pelo cunho erótico presentes nestas obras. Algo similar foi recorrente com Adelaide Carraro, outra escritora que enfrentou o controle néscio da Censura. 
o cotidiano das classes populares. Estes temas, ao exporem a crueza e as relações até mesmo catárticas desta população em relação ao status $q u o$, por sua vez, não correspondiam ao ideário do desenvolvimentismo, da moralidade e da euforia propalada pelos militares. A discografia da dupla na década de 1970 e início da da década seguinte são expressões deste inconformismo traduzido em letras musicais pelo carioca Blanc e na música original e precisa de seu parceiro mineiro Bosco. Estes discos traziam uma renovação estética na chamada música popular brasileira, produzindo diferentes análises dos críticos musicais sobre o gênero ou movimento musical que marcaria tal obra. Ora enquadrados nos gêneros musicais como samba, samba-canção, bolero ou outros gêneros tradicionais, ora tomados como expressões de um neotropicalismo, na verdade realizavam bricolagens destes diferentes ritmos. Afinal, "A bricolagem se aplicou aos estudos de música popular principalmente ao considerar a natureza e significados do estilo cultural, especialmente nas subculturas juvenis e em relação com as apropriações musicais" (SHUKER, 2005, p. 50 e 51 ).

Analisara cotidianidade, por sua vez, demanda uma reflexão sobre a natureza do conceito. Sua acepção que engloba o corriqueiro, o banal, o repetível, pode fugir à dinâmica social, ainda que esta realidade social revele a banalidade daquilo que caracteriza uma dimensão macro e estrutural das sociedades. São óbvias as mediações entre as estruturas econômicas e sociais e as vicissitudes da vida cotidiana, contudo, pensar sobre o cotidiano é desenredar como estas estruturas interferem na vida comum. Como diria a filósofa Agnes Heller, que não entende cotidiano como aquelas meras ações repetitivas, ordinárias e rotineiras: "A vida cotidiana é a vida do indivíduo. O indivíduo é sempre, simultaneamente, ser particular e ser genérico." (HELLER, 2004, p.20). Este ser unívoco não se descola da sociedade em que vive, de sua vida reverbera seu vínculo social:

Também enquanto indivíduo, portanto, é o homem um ser genérico, já que é produto e expressão de suas relações sociais, herdeiro e preservador do desenvolvimento humano; mas o representante do humano-genérico não é jamais um homem sozinho, mas sempre a integração (tribo, demos, estamento, classe, nação, humanidade) - bem como, frequentemente, várias integrações - cuja parte consciente é o homem e na qual se forma sua 'consciência de nós'. (HELLER, 2004, p.21.)

As diferentes expressões musicais que aliaram letra e música ao longo da história revelaram visceralmente as vicissitudes sociais. Ao tratar estas canções em sua instância narrativa, tomamos como mote as ideias da pesquisadora espanhola Victoria Sau: "Literariamente, são novelas abreviadas, em síntese" (1972, p.13). Portanto, o cancioneiro popular produz leituras sociais, revela histórias, construindo outras falas sociais, revelando a partir de outra ótica, mediada pelas expressões artísticas, colocando em primeiro plano outras vozes.

Nesse sentido, sobre a canção popular urbana brasileira, José Geraldo Vinci de Moraes, em seu profícuo artigo sobre as relações entre música e história, revela: "a canção é uma expressão artística que contém um forte poder de comunicação, principalmente quando se difunde pelo universo urbano, alcançando ampla dimensão da realidade social"(MORAES, 2000, p.204).

Por conseguinte, ao pensarmos a vida cotidiana urbana a partir do cancioneiro popular no século XX, por exemplo, encontramos os pilares da canção moderna. Até mesmo no cancioneiro dos Beatles o cotidiano aparece como leitmotiv: "Em algumas ocasiões um acontecimento qualquer do cotidiano lhes serviu de mote para canções, mas eles se influenciavam muito mais por outras músicas do que por histórias de suas vidas" (TURNER, 2009, p.11). Já, a partir de 1966, os Beatles denotam um amadurecimento artístico que faz com que: “[...] extraíam ideias para canções de conversas ouvidas por acaso, anedotas, manchetes de jornal, livros esotéricos. Pôsteres, sonhos, comerciais de televisão, pinturas e eventos cotidianos" (Idem, p.14).

Aqui, elegemos a produção da dupla Bosco/ 
Blanc, portanto, das camadas médias, mas outra possibilidade seria prospectar a produção desta própria população marginalizada. Outro dado é que se estas canções tematizam o cotidiano, elas mesmas terminam por se inserir no dia a dia dos ouvintes pelos meios de comunicação de massa e pelo disco: "O cotidiano das pessoas foi transformado irreversivelmente pelo rádio, disco, profissionalização dos artistas, lógica dos espetáculos e imprensa especializada" (MORAES, 2000, p.216). Esta lógica da universalização da escuta sonora provocou um forte impacto social:

A música, entretanto, no século XX, e pela primeira vez na história, rompeu a muralha da comunicação puramente física entre instrumento e ouvido. A esmagadora maioria dos sons e ruídos que ouvimos como experiência cultural hoje nos chega por via indireta - mecanicamente reproduzida ou transmitida à distância. (HOBSBAWN, 2013, p.28)

\section{O cotidiano na obra de João Bosco e Aldir Blanc}

O LP Tiro de Misericórdia, de 1977, de João Bosco, dentro da temática do cotidiano popular, trazia diversas leituras da realidade dos subúrbios das grandes cidades brasileiras e seus personagens mais comuns: o menino pobre (Gênesis e Tiro de Misericórdia), o jogador (Tabelas e Jogador), o boêmio (Me dá a penúltima), os retirantes (Vaso ruim não quebra).

Em Tabelas, por exemplo, a dupla narra as indas e vindas dos três personagens principais do filme O Jogo da Vida, de Mauricio Capovilla, de 1977: “(...) carregar nossa cruz feito o menino Perus/ cair na sarjeta que nem Malagueta/ ou virar bagaço que nem Bacanaço". Eles foram encarregados da composição tema do filme, cuja direção da trilha sonora coube ao paradigmático maestro Radamés Gnatalli, com quem já tinham trabalhado anteriormente. Este filme, por sua vez, é uma adaptação da obra Malagueta, Perus e Bacanaço, do escritor João Antônio, baseada em suas experiências de boêmio em São Paulo. Ele concluiu a história em 1960, mas um incêndio queimou os originais e ele tardou mais dois anos para reescrevê-la. A exemplo das canções da dupla, o autor traduz sua obra como: "Um corpoa-corpo com a vida brasileira. Uma literatura que se rale nos fatos e não que rele neles" (ANTONIO, 1986, p. 06).

Portanto, não foi fortuita esta parceria entre literatura, cinema e canção, uma vez que todos os envolvidos tomam o universo popular como mote para a criação artística e política, ainda mais neste contexto ditatorial. Apesar dos temas e de sua tragicidade inerente, o cancioneiro da dupla também trabalha, em alguma instância, com a ironia, com o riso e com o flerte, com imagens do clichê e do kitsch na composição das personagens, reverberando até na escolha dos gêneros musicais para compor este ambiente musical. O conceito de kitsch, de certo modo, se relaciona a uma parte das personagens e situações que orbitam no cancioneiro de Bosco e Blanc. Não o resultado dessas inflexões e criações artísticas, a canção, que obviamente não se aproxima de uma estética kitsch, mas o substrato que as dão forma, ainda que ironicamente: as personagens e suas idiossincrasias. A palavra kitsch, de origem alemã, guarda aquilo que deve ser ocultado, que é risível ou imoral, mesmo escatológico, ainda que inteiramente pertencente à cotidianidade, ao day by day, à natureza humana, ao sentimentalismo pueril. Milan Kundera, em uma discussão sociológica no interior de seu grande romance $A$ insustentável leveza do ser, categoriza o termo:

Esse ideal estético chama-se kitsch. É uma palavra alemã que apareceu em meados do século XIX sentimental e que depois se vulgarizou em todas as línguas. Mas a sua utilização frequente fê-la perder todo o valor metafísico original: o kitsch é, por essência, a negação absoluta da merda; tanto no sentido literal como no sentido figurado, o kitsch exclui do seu campo de visão tudo o que a existência humana tem de essencialmente inaceitável (KUNDERA, 2008, p.243).

Esta construção de personagens eivados desta singeleza vociferante, tem na obra da dupla um suporte dado por algum gênero musical, ou por uma bricolagem destes, como em Miss 
Suéter, do disco Galos de Briga (1976), que traz a escriturária do INPS, que tem sua narrativa disposta num bolero, contribuindo para a feitura da personagem e da narratividade da canção.

Essas canções trazem um cenário suburbano da periferia das grandes cidades e são marcas ainda presentes na sociedade brasileira. A obra da dupla centra seu olhar no cotidiano das classes populares e é desta que são extraídos os diferentes problemas por qual elas passam. A música da dupla nos insere, também, na dura realidade vivida pelas crianças mais pobres, como em Gênesis, que traz um cenário suburbano, que pode estar na periferia de qualquer espaço urbano. Traz a vida de um menino diferente de Jesus na manjedoura: "quando ele nasceu/ nasceu de birra/barro ao invés de incenso e mirra/ cordão cortado com gilete". O ambiente é sempre repleto de acontecimentos, inúmeras imagens que se sobrepõem: "quando ele nasceu/sacaram o berro/ meteram a faca/ ergueram ferro...".

\section{Gênesis (Parto)}

Quando ele nasceu

foi no sufoco...

tinha uma vaca, um burro e um louco que recebeu seu sete...

quando ele nasceu

foi de teimoso

com a manha e a baba do tinhoso.

chovia canivete...

quando ele nasceu nasceu de birra...

barro ao invés de incenso e mirra, cordão cortado com gilete...

quando ele nasceu

sacaram o berro,

meteram a faca, ergueram o ferro...

Exu falou: ninguém se mete!

quando ele nasceu tomaram cana,

um partideiro puxou samba...

Oxum falou: esse promete...

O nascimento de Jesus sofre uma paródia incisiva no tocante à desigualdade social, pois a criança já nasce no sufoco, de birra, de teimoso. E, como numa imagem carnavalizada, aquele nascimento é comemorado com cachaça, samba e candomblé. Aliás, seria desta religiosidade africana que viriam as sonoridades que fazem parte dos referenciais musicais de João Bosco e do universo literário de Aldir Blanc.

Ao ouvir uma canção como esta, não há como não se reportar a estas influências africanas na cultura do samba. Aliás, não só na música, também numa religiosidade expressa nas falas ao fundo da canção, que nos levam ao terreiro, aos Orixás. Se há na obra da dupla uma transversal do tempo, também há uma transversal do espaço. Afinal, a África também é aqui. Da cultura iorubá, em especial, surge todo o sincretismo religioso e a musicalidade brasileira. Esta influência musical é perceptível tanto no canto responsorial quanto na parte rítmica. Os tambores são uma constante nas composições da dupla. E neste samba não é diferente. Apesar de a música trazer um tema triste, a percussão parece dizer uma outra coisa, como se expressasse a força e a resistência do menino ante todas as adversidades. Talvez esta reflexão revele um outro dado da cultura africana que é a convivência com a dualidade da personalidade. Não se desqualifica uma coisa para valorizar outra, como o que foi feito pelos europeus, por exemplo, com Exu.

A relação dos Orixás com a natureza também está presente no trabalho percussivo, como na introdução de Gênesis. Ali, sons de pássaros, silvos e vozes nos levam a um universo religioso. Entre estas vozes, João Bosco trabalha com aquilo que ele chama de "sonoridades": palavras desconexas que, apesar de não terem um significado para a nossa língua, traduzem parte daquilo que se quer expressar. No verso: "Exu falou: ninguém se mete", João Bosco imita a voz de "preto velho",

3 Entidade cultuada como uma das sete linhas da Umbanda. 
que lhe é peculiar. O nascimento do menino é apresentado numa versão brasileira, em meio à violência: à faca, ao berro (revólver), gilete, canivete. Qual seria o destino do menino neste ambiente? "Oxum falou: esse promete....

A influência africana e a crítica às condições de vida de boa parte das crianças e jovens brasileiros são retomadas em "Tiro de Misericórdia". Nesta canção temos novamente uma concepção musical semelhante: a influência de manifestações rítmicas e vocais da cultura africana. Uma influência musical que se expandiu pela América com o tráfico de escravos africanos, e que possibilitou semelhanças entre os ritmos de diferentes países. A canção traz a história do menino pobre que "cresceu entre a ronda e a cana/ correndo nos becos que nem ratazana" e que - como muitos meninos de rua - foi assassinado: "grampearam o menino de corpo fechado/ $e$ barbarizaram com mais de cem tiros/ treze anos de vida sem misericórdial e a misericórdia no último tiro."

Porém, a morte do menino representa mais do que o crime em si, aponta para todas as desigualdades e violências cometidas no mundo: “irmãos, irmãs, irmãozinhos/ nem tudo está consumado/ a minha morte é só umal ganga, lumumba, lorca, jesus." Neste trecho, o tempo é "diluído" e líderes assassinados em várias épocas são colocados lado a lado: Ganga Zumba, rei dos Palmares; Patrice Lumumba, líder na luta pela independência no Congo (antiga colônia belga); o poeta espanhol García Lorca, morto pelas forças de repressão do general Franco; e o principal líder religioso da história, Jesus Cristo. Este último é sugestionado ainda pela passagem; "Por que me abandonaram? Por que nos abandonamos em cada cruz?".

A canção é uma narrativa e está dividida numa parte cantada e numa outra (o trecho em itálico) em que João Bosco discursa boa parte da letra da canção, neste momento, parte desta oratória não é audível, ou propositalmente, ou por falha técnica. Só é compreensível com o encarte do disco em mãos para poder acompanhar a letra. Esta fala remete a um culto africano, Candomblé ou Umbanda, como se a 3 a pessoa que narra fosse um pai-de-santo, recebendo um Orixá.

\section{Tiro de Misericórdia}

O menino cresceu entre a ronda e a cana correndo nos becos que nem ratazana. entre a punga e o afano, entre a carta e a ficha subindo em pedreira que nem lagartixa. Borel, juramento, urubu, catacumba, nas rodas de samba, no eró da macumba. matriz, querosene, Salgueiro, turano, Mangueira, São Carlos, menino mandando, ídolo de poeira, marafo e farelo, um Deus de bermuda e pé-de-chinelo, imperador dos morros, reizinho nagô, o corpo fechado por babalaôs.

baixou oxolufã com as espadas de prata, com sua coroa de escuro e de vício. baixou caô-xangô com o machado de asa, com seu fogo brabo nas mãos de corisco. Ogunhê se plantou pelas encruzilhadas com todos seus ferros, com lança e enxada. e Oxossi com seu arco e flecha e seus galos e suas abelhas na beira da mata.

e Oxum trouxe pedra e água da cachoeira em seu coração de espinhos dourados. Iemanjá, o alumínio, as sereias do mar e um batalhão de mil afogados.

Iansã trouxe almas e os vendavais, adagas e ventos, trovões e punhais. Oxum-maré largou suas cobras no chão. soltou sua trança, quebrou o arco-íris. Omolu trouxe o chumbo e chocalho de guizos lançando a doença pra seus inimigos. e nanã-buruquê trouxe a chuva e a vassoura pra terra dos corpos, pro sangue dos mortos.

Exus na capa da noite soltaram a gargalhada e avisaram as ciladas pros orixás.

Exus, orixás, menino lutaram como puderam mas era muita matraca para pouco berro. e lá no Horto maldito, no chão de pendura-

saia

Zambi menino lumumba tomba na raia mandando bala pra baixo contra as falanges 
do mal,

arcanjos velhos, coveiros do carnaval.

- irmãos, irmãs, irmãozinhos, por que me abandonaram?

por que nos abandonamos em cada cruz?

- irmãos, irmãs, irmãozinhos,

nem tudo está consumado.

a minha morte é só uma:

ganga, lumumba, lorca, jesus...

grampearam o menino de corpo fechado e barbarizaram com mais de cem tiros. treze anos de vida sem misericórdia e a misericórdia no último tiro.

morreu como um cachorro e gritou feito um porco

depois de pular igual a macaco vou jogar nesses três que nem ele morreu: num jogo cercado pelos sete lados.

A canção também refaz o calvário de Jesus através deste menino. Algumas passagens trazem uma certa dubiedade, por exemplo, ronda (polícia?) e cana (bebida, prisão), punga (produto do roubo ou samba de roda), carta (jogo?), ficha (policial?). A história deste menino retoma a canção Gênesis, como se aquela criança estivesse agora com treze anos.

Até os números são sugestivos: treze anos, número do azar; num jogo cercado pelos sete lados, um número notadamente cabalístico. Roger Bastide (1978, p. 166-8) enfatiza a importância dos números no Candomblé e recupera como eles são freqüentes: 7 Ogum, 7 Iemanjá, 14 Omolu. Remete, ainda, as sete linhas e sete falanges na Umbanda. No mesmo caminho: vou jogar nesses três: a Santíssima Trindade? Neste último, podemos fazer uma ponte com a alusão a Jesus na cruz, "Senhor, por que me abandonaste?". Chico Buarque fez a mesma alusão em Minha História, ao parodiar a história do menino Jesus, nascido de um caso entre um marinheiro e uma prostituta, por meio de uma versão da canção Gesubambino, de Lucio Dalla e Pallotino: “(...)
Minha história, esse nome que ainda carrego comigo/ Quando vou para um bar, / viro a mesa, berro, bebo, brigo/ Os ladrões e as amantes/meus colegas de copo e de cruz/ me conhecem só pelo meu nome de menino Jesus".

A exemplo da Paixão de Cristo, Tiro de Misericórdia retoma outros mártires, mesmo que não reconhecidos como tais, como Zambi, Ganga Zumba, Lumumba e Lorca. Se tomarmos como referência à definição de paixão, além daquela do martírio, teremos um outro significado. Afinal, para a música, seria: "um gênero de cantata ou oratório religioso cujo tema são os acontecimentos que precederam e acompanharam a morte de Cristo" (HOLANDA FERREIRA, 1986).

Este significado se aplica bem à trajetória do menino. Da manjedoura improvisada de Gênesis até a morte com cem tiros, pondo fim aos treze anos de vida sem misericórdia e a misericórdia no último tiro. Ele vivia num dos morros cariocas: Borel, Salgueiro, Mangueira e São Carlos, que por sinal, além de serem ocupados por favelas, também são redutos de escolas de samba.

Se Jesus era o "rei dos judeus", o menino era o deus tupiniquim, mais vulnerável, afinal, seria como uma estátua feita de poeira, marafo (cachaça) e farelo. Por sinal, Exu tem como comida preferida: o galo, a cachaça e a farofa. Era o imperador dos morros, com o corpo fechado e sob a proteção dos mais diferentes Orixás e suas respectivas armas: Ogunhê (ferros), Oxolufã (espadas de prata), Oxossi (arco e flecha), Iansã (trovões e punhais), Caô-Xangô (machado de asa). Porém, a exemplo de Jesus vencido e abandonado pelo pai; também o menino é derrotado, mesmo tendo a ajuda de Exus e Orixás que, por sua vez, não conseguem vencer o inimigo consubstanciado nas falanges do mal, arcanjos velhos, coveiros do carnaval. Para se explorar um pouco mais sobre estas entidades, vale lembrar que, na Umbanda, os Orixás principais estão, geralmente, divididos por "sete linhas", sendo que cada uma destas congrega mais "sete falanges ou legiões". Daí a idéia de "falanges do mal".

A canção alude às religiões afro-brasileiras, em especial, ao Candomblé e à Umbanda. Apesar de serem confundidas e de possuírem diferenças 
regionais, guardam muitas particularidades. A Umbanda é bem mais recente, criada na década de 1920, por camadas médias da sociedade ligadas ao kardecismo e constituindo-se a partir da contribuição das diferentes culturas: negra, indígena e branca. Tem menos ligações com suas raízes africanas, resultado do sincretismo religioso, com o catolicismo, por exemplo, e é mais urbana. É apoiada, ainda, em um certo racionalismo do kardecismo, associando-se a cultos mais universais, como os conhecimentos esotéricos e cabalísticos. O Candomblé, por sua vez, bem mais antigo, tende a valorizar mais os referenciais africanos, mantendo-se o mais próximo possível da música e rituais africanos e buscando recriar e "reinventar a África no Brasil" (SILVA, 1994). A partir do trecho "irmãos, irmãs, irmãozinhos (...)", um órgão ao fundo remete a uma marcha fúnebre, a exemplo da canção Agnus Sei, da mesma dupla. Esta escolha foi feita não apenas pelo momento da morte do menino, como também pela lembrança dos outros mártires. A dor também é expressa pelas interjeições de "ai, ai, ai” e pela cuíca ao longo da canção, reproduzindo um som semelhante a gemidos e soluços.

Pensando o disco em sua totalidade, temos um outro dado significativo da obra da dupla Bosco/ Blanc, ou seja, a concepção das capas dos discos. Elas são a "comissão de frente" das composições, são capas marcantes e incisivas. A criação da capa do disco Tiro de Misericórdia esteve a cargo do artista Mello Menezes. Nela, inúmeras imagens se sobrepõem. A imagem central é do menino Jesus na manjedoura, só que esta é feita de maçã (com toda sua simbologia bíblica), tendo em volta: João Bosco e seu violão, um rei caracterizado como um pai de santo, alguns animais, dois grupos de porta-estandartes. Os componentes destes grupos, porém, são completamente diversos, como a moça com a faixa "miss balconista", tão lembrada nas canções da dupla. O fundo tem vários tons de azul e acima da criança um telhado típico dos barracos da periferia e, sobre este, um cometa como na imagem sacralizada do nascimento de Jesus, só que este cometa é uma bala que corta o céu.

Esta imagem caracteriza bem as péssimas condições de vida de amplas camadas da população. Algo que não foi criado pela ditadura, mas expandido por ela. $\mathrm{Na}$ contra-capa, o resultado: não mais um menino, mas agora um homem esquelético pendurado num poste, como numa imagem do calvário, em volta, os mesmos dois grupos, só que assustados, como naquela cena de Picasso, em sua Guernica. Ao pé da "cruz" um homem sentado folheando um livro, algo parecido com um sacerdote. A capa coincide com a representação carnavalizada e irônica aliada a uma tragicidade peculiar presente na obra da dupla Bosco/ Blanc.

De certa maneira, ainda que as paisagens remetam ao Rio de Janeiro em boa parte destas canções, o elemento urbano aproxima outras realidades, outras cidades. A dupla constrói uma imagem caleidoscópica da cidade, com suas contradições, com o humor carioca, com os costumes, com um desfile de personagens ora caricatos, ora complexos. São também retratos dos olhares dos compositores. João Bosco acabou por não exercer a profissão de engenheiro, na qual se formou em Minas Gerais, dedicando-se à música, ao passo que Aldir ainda trabalhou alguns anos no exercício da Medicina, em particular da Psiquiatria, exercida durante três anos num hospital no Engenho de Dentro, no Rio de Janeiro, onde, segundo ele próprio: "havia gente no chão, sem roupa, faltavam colchões, roupa de cama, casacos, calçados e remédios" (O Globo, 10 set.1976, p.10). Esta representação do espaço urbano nos remete às reflexões de Alcyr Lenharo, sobre a obra de Adoniran Barbosa e das imagens paulistanas em seu cancioneiro, que, de certo modo, se relacionam ao trabalho de Bosco e Blanc no Rio de Janeiro, e no pensamento de Agnes Heller sobre o cotidiano e o indivíduo:

De um lado, temos pela frente uma memorização de cidade, geradora de uma tensão entre o 'eu' articulador do artista e o urbano institucional. De outro lado, o autor insiste em coletar os seus fragmentos, e em configurar o urbano, ainda que a cidade se mantenha à esquiva de sua inciativa (LENHARO, 1985, p. 51). 
Não foi o espaço urbano o único ambiente representado pela dupla por meio de canções. As classes populares também foram lembradas em $O$ rancho da goiabada ${ }^{4}$, em que o bóia-fria é retratado de forma muito sensível e onde sua amargura está lado a lado com uma fina ironia. Composta num tom de Mi menor (Em), esta canção tem uma melodia triste, como é o cotidiano destes trabalhadores espalhados por todo o Brasil, que só na década de 1960 tiveram algumas leis trabalhistas a seu favor, com exceção ainda do $13^{\circ}$ salário. É o trabalhador sofrido que é "transportado" em caminhões antes da cinco da manhã, que leva sua marmita fria e água, por vezes, acondicionada em velhos vasilhames de agrotóxicos. Entre estes trabalhadores, inúmeras crianças. Assim, nas escolas rurais, dois motivos implicam na ausência dos alunos em sala: a colheita/plantio e a falta de merenda.

Esta mão-de-obra é, em sua maioria, formada por pessoas que venderam ou tiveram suas terras expropriadas e que quando ainda tinham sua posse não tinham financiamento nem apoio governamental na produção, no beneficiamento, no uso da tecnologia, na distribuição dos produtos. Algo bem diferente das grandes empresas agropecuárias que, além de obterem empréstimos, por vezes têm suas dívidas perdoadas. Não é um problema datado, como se vê.

\section{O rancho da goiabada}

Os bóias-frias

Quando tomam umas biritas

Espantando a tristeza

Sonham com bife a cavalo

Batata frita

E a sobremesa

É goiabada cascão

Com muito queijo

Depois café, cigarro

E um beijo de uma mulata
Chamada Leonor ou Dagmar

Amar

O rádio de pilha

O fogão jacaré

A marmita, o domingo, o bar

Onde tantos iguais se reúnem

Contando mentiras

Pra poder suportar

$\mathrm{Ai}$ são pais-de-santo,paus-de-arara, são passistas

São flagelados, são pingentes balconistas

Palhaços, marcianos, canibais lírios pirados

Dançando, dormindo de olhos abertos

À sombrada alegoria dosfaraósembalsamados

A dupla utiliza o tradicional gênero marcharancho para apresentar um tema nada tradicional na música popular. A vida e os sonhos desses trabalhadores tem uma descrição milimétrica: "amar o rádio de pilha/ o fogão jacaré/ a marmita, o domingo, o bar." Uma realidade tão dura, "contando mentiras pra poder suportar", em que o sonho passa por uma "goiabada com queijo". Registrada no disco Galos de Briga (1976), esta música traz o arranjo do maestro Radamés Gnatalli, um dos primeiros arranjadores a trabalhar no rádio, na década de 1930, e precursor da utilização de orquestras em gravações de canções populares.

Os metais dão a tônica do gênero e o canto coletivo lembra a massa de trabalhadores rurais em sua batalha diária, ou ainda, o canto em uníssono das pessoas que participavam dos antigos blocos carnavalescos. Estão no coro: o office-boy, a telefonista, o porteiro, a secretária, o produtor, entre outros que trabalhavam na gravadora RCA do Rio de Janeiro, onde foi gravado o disco. A idéia de formar um coro com amadores dá bem a idéia da configuração dos antigos ranchos carnavalescos.

Contudo, os autores apontam um problema mais imediato que aflige estes trabalhadores: 
a fome. Aldir Blanc, numa entrevista para o livro Patrulhas Ideológicas, lembra a crítica que ele sofreu em alguns jornais por ter colocado, justamente nesta canção, a fome como problema mais imediato do que a posse da terra. Afinal, este seria o resultado mais perverso dessa estrutura fundiária e da configuração do capitalismo nos países mais pobres. A canção toca num ponto trágico da sociedade brasileira e que não se restringe aos bóias-frias. Em Nação, de Bosco, Blanc e Paulo Emílio, em célebre gravação de Clara Nunes de 1982, o tema da fome é retomado: "Jêje, minha sede é dos rios// A minha cor é o arco-íris// Minha fome é tanta”. Por conseguinte, obra da dupla Bosco/Blanc fala de um:

(...) Brasil de verdade, da maioria e não dos marginais, como pode parecer para quem olhar apressadamente os personagens de suas canções. A minoria, que está à margem do Brasil verdadeiro é aquela turma que conta com o indispensável, do alimento à saúde e informação. A maioria, ao contrário, não dispõe desses luxos marginais (BOSCO, BLANC, 1983).

Apesar de nosso recorte no cancioneiro das décadas de 1970 e 1980, a dupla realizou um diálogo com o passado nesse período, mesmo o mais remoto. As canções trazem uma espécie de ambientação, em que são postos as personagens e seus temas. Diálogo este, estabelecido não apenas na narratividade da letra, mas também no gênero e nos arranjos utilizados, como nos referimos anteriormente. O trabalho com estas diferentes temporalidades enriquece e traz uma originalidade marcante dentro da MPB. Além dos autores reportarem suas canções ao fundo musical de suas infâncias e adolescências, também foram freqüentes os intertextos e mesmo a coexistência de tempos distintos numa mesma canção. No entanto, isto não se traduz num anacronismo, e sim num recurso criativo amplamente utilizado pelos autores, não apenas para burlar a Censura, mas também para enriquecer o texto musical. Este trânsito por diferentes temporalidades pode ser encontrado em diversas canções e seria uma espécie do que João Bosco e Aldir Blanc chamam de transversal do tempo - homônimo de uma canção da dupla.

Esta transversal pode ser observada em inúmeras canções, como em 100 anos de Instituto - anais, do disco Bandalhismo (1980). Nela, a personagem central é uma jovem, aluna de um Instituto de Educação, como normalista, "especialista em canto orfeônico", descrição que causa estranhamento se pensarmos em 1980, mas convincente na narrativa. $O$ gênero musical alude ao bolero e à década de 1950, tempo em que Aldir Blanc relembra dos variados discos de $78 \mathrm{rpm}$ comprados por sua avó, entre eles, alguns de tango, que enchiam de música a casa em que morava na Vila Isabel, no Rio de Janeiro. Estas lembranças citadas em seu livro Vila Isabel: Inventário da Infância denotam bem a influência trazida pelo rádio e pelos diferentes gêneros musicais em suas composições. Porém, vale lembrar que estas rememorações traduzidas em canções são também pontuadas por temas pertinentes ao momento de sua produção, pois, ao tratar do baixo mundo e do cotidiano popular, há uma preocupação em trazer à tona personagens não muito presentes nas composições da década de 1970. É exposta a história de gente comum, como aquela classe lembrada na década de 1950 pelo livro Quarto de Despejo, da favelada Carolina Maria de Jesus:

\footnotetext{
A rigor, no livro de Carolina encontra-se boa parte de uma cultura urbana que, tanto naqueles anos cinqüenta como em nossos dias, amplia-se cada vez mais. É a cultura dos excluídos que, ironicamente, quanto mais cresce, quanto mais aumenta seu contingente, mais desconhecida se torna. Podese até mesmo dizer que a cultura da comunidade marginal brasileira é a cultura da angústia e da tragédia humana (CALDAS, 1995, p. 111).
}

Interessante como a história de Carolina é semelhante à história presente na canção Essa é a sua vida, que deu nome a outro disco da dupla. Basta lembrar a verdadeira epopéia por qual passou Carolina: de favelada a conhecida escritora. No livro, ela descreve toda a tragédia 
de mãe, negra, pobre, favelada e desempregada. Com a publicação e a boa aceitação do público pôde comprar uma casa, ser convidada a palestrar na Europa, ser recebida por presidentes, como nos trechos da canção: ser atriz!/ ser feliz!/ exfavelada conquista Paris! Porém, perde tudo ao não conseguir a mesma vendagem nos livros que se seguiram, voltando a morar numa favela em São Paulo e, no início de 1977, "numa madrugada de domingo, Carolina Maria de Jesus morreu em meio ao lixo e aos urubus. Ninguém lembrava da mulher que escrevera: 'A fome é a dinamite do corpo humano"' (GALEANO, 1989, p. 303).

Como a sonhadora moça da canção, volta à realidade:

\section{Essa é a sua vida}

Ser atriz!

Ser feliz!

Ex-favelada conquista Paris!

Jóias, corbeilles,

Gritos de bis,

Um gentil-homem

Que lembra Aramis,

Ter sempre carne, licor de anis...

No balcão,

Serve em pé

Pra um funcionário,

Pra um operário,

Pra um otário qualquer...

O avental azul...

Os seus sonhos...

Manchas de café.

Esta canção dificilmente pode ser enquadrada num gênero musical, como afirmamos anteriormente sobre bricolagens, apesar de lembrar um tango, como transparece pela utilização do acordeón. Esta é uma outra característica das composições da dupla: a miscelânea de gêneros, como declara Aldir Blanc para o fascículo Nova História da MPB: “João faz uma melodia. As pessoas rotulam: 'É tango, é bolero, é rumba'. Na verdade, a gente faz essa variedade de ritmos porque, no fundo, não está preocupado em fazer gênero algum. Quem dá o nome são os ouvintes" (1977, p. 08). Além do acordeón, o arranjo de Aizik Geller traz o violão de João Bosco, um piano acústico e cordas. A tristeza expressa na letra é maximizada pela música, em especial, pela intervenção do acordeón. A balconista, já tematizada numa canção da dupla intitulada Fatalidade, de 1973, é fruto das incursões dos compositores pelo subúrbio carioca: "duas instituições nacionais - os salões de bilhar e os restaurantes estilo 'sujinho' - fazem parte do cotidiano da dupla João Bosco-Aldir Blanc, desde que ela se formou" (NOVA HISTÓRIA da MPB, 1976, p. 10). Estes ambientes estão refletidos na vida da moça da canção Essa é sua vida que, atrás do balcão, sonha em ter sempre carne/ licor de anis, ou, ainda, em estar sob a mira dos olhos de um homem cortês, expresso no mosqueteiro Aramis, de Alexandre Dumas.

Por fim, parte significativa do cancioneiro da dupla se reporta à história, e fração desta mesma obra retorna à reflexão histórica posterior, quando as próprias canções se constituem em documento histórico e suporte de memórias do passado e do cotidiano pretérito:

\begin{abstract}
A vida cotidiana não está 'fora' da história, mas no 'centro' do acontecer histórico: é a verdadeira 'essência' da substância social [...] As grandes ações não cotidianas que são contadas nos livros de história partem da vida cotidiana e a ele retornam. Toda grande façanha histórica concreta torna-se particular e histórica precisamente graças a seu posterior efeito na cotidianidade. $O$ que assimila a cotidianidade de sua época assimila também, com isso, o passado da humanidade, embora tal assimilação possa não ser consciente, mas apenas 'em si' (HELLER, 2004, p.20).
\end{abstract}

\section{Considerações finais}

Estas canções aqui retomadas revelam das obviedades da precariedade vivida pelos pobres às minúcias, sutilezas e filigranas da cotidianidade no período. Imagens, sons, a plasticidade do disco, a indústria, a censura, a metáfora e uma 
luta povoando o cenário musical brasileiro nos anos de 1970, mas não só na música, o que é mais trágico. Elas lançam um olhar por vezes ferino, irônico e dantesco sobre a realidade das classes populares. O corpo estendido no chão em $D e$ frente pro crime; a moça atropelada de Fatalidade; a angústia da moça triste enredada em seu vestido a esperar o marido infiel em Bodas de prata e o "tempo lhe comendo feito traça num vestido de noivado". Da balconista, da normalista, dos homens nos bares bebendo esquecimento, dos bóias-frias sonhando com goiabada cascão com queijo, da violência de gênero, das idiossincrasias, da pobreza, da favela, do ronco da fome na barriga da miséria, dos meninos assassinados na periferia; mas, também o riso, a alegria, o humor, a persistência, a malemolência, a euforia vestida de passista e porta-estandarte, a paixão avassaladora em ritmo de bolero. Portanto, da felicidade, dos dilemas e do desassossego dos homens e mulheres comuns que não ficaram no passado.

\section{Referências bibliográficas}

ANTÔNIO, João. Malagueta, Perus e Bacanaço. São Paulo: Ática, 1987.

BASTIDE, Roger. O Candomblé da Bahia: Rito Nagô. 2 ed. Trad. Maria Isaura de Queiroz. São Paulo: Companhia Editora Nacional/ MEC, 1978.p. 166-8.

BLANC, Aldir. Vila Isabel: inventário de infância. Rio de Janeiro: Relume-Dumará: Prefeitura, 1996. (Cantos do Rio; 5).

CALDAS, Waldenyr. Iniciação à Música Popular Brasileira. 2 ed. São Paulo: Ed. Ática, 1989. (Série Princípios)

GALEANO, Eduardo. As veias abertas da América Latina. 29 ed. Rio de Janeiro: Paz e Terra, 1989. (Estudos latino-americanos; 12).

HELLER, Agnes. O cotidiano e a história. 7 ed.
São Paulo: Paz e Terra, 2004.

HOBSBAWN, Eric. Tempos fraturados: cultura e sociedade no século XX. São Paulo: Companhia das Letras, 2013.

HOLANDA FERREIRA, Aurélio B. Novo Dicionário da Língua Portuguesa. 2 ed. - rev. e aum., 18 a impr. - Rio de Janeiro: Nova Fronteira, 1986.

KUNDERA, Milan. A insustentável leveza do ser. (Trad. Teresa Bulhões) São Paulo: Companhia das Letras, 2008.

LENHARO, Alcyr. Luzes da cidade. Revista Oculum, n.1, ano II, ago. 1985, pp. 50-5.

MORAES, José Geraldo Vinci de. História e música: canção popular e conhecimento histórico. Revista Brasileira de História. São Paulo, v. 20, nº 39, p. 203-221, 2000.

PEREIRA, Alberto, HOLLANDA, Heloísa B. de. Patrulhas ideológicas - marcas reg.: arte e engajamento em debate. São Paulo: Brasiliense, 1980.

SAU, Victoria. Historia antropológica de la canción. Barcelona: Ediciones Picazo, 1972.

SHUKER, Roy. Diccionario del rock y la música popular. Barcelona: Robinbook, 2005, p. 50 e 51

SILVA, Vagner Gonçalves da. Candomblé $e$ Umbanda: caminhos da devoção brasileira. São Paulo: Ática, 1994.

TURNER, Steve. The Beatles: a história por trás de todas as canções. São Paulo: Cosac Naify, 2009.

\section{Discografia}

BOSCO, João. Bandalhismo. Rio de Janeiro: RCA, 1980. $33 \mathrm{rpm}$, stereo, $\mathrm{n}^{\circ} 110.0022$. 
Essa é Sua Vida. Rio de Janeiro: RCA, $1981.33 \mathrm{rpm}$, stereo, $\mathrm{n}^{\circ} 110.0023$.

. Galos de Briga. Rio de Janeiro: RCA, 1976. $33 \mathrm{rpm}$, stereo, $\mathrm{n}^{\circ} 103.0171$.

Tiro de Misericórdia. Rio de Janeiro: RCA, 1977. $33 \mathrm{rpm}$, stereo, $\mathrm{n}^{\circ} 103.0228$.

BOSCO, João, BLANC, Aldir. Nova História da $M P B$. São Paulo: Abril Cultural, 1976. 33 rpm, ${ }^{\circ}$ HMPB-04, stereo.

História da Música Popular Brasileira. São Paulo: Abril Cultural, 1983. 33 rpm, stereo. 